\title{
Effect of Sampling Conditions on the Composition of the Volatile Phase of Cigarette Smoke*
}

\author{
by P. Ceschini and D. Cham \\ Scientific Department of Ed. Laurens SA, Geneva
}

\section{INTRODUCTION}

In the field of tobacco smoke studies the chemical and biological aspects of the particulate matter of tobacco smoke have been especially investigated during the last years.

But in the Tobacco-Health controversy more attention has now been focused on the importance of the volatile phase components and many investigators have tried to detect their effect on the respiratory tract.

Although free from any biological considerations our investigations appear to be of interest inasmuch as they reveal the effect of various sampling conditions on the composition of the volatile phase.

\section{OBJECTIVES}

During this study we more particularly investigated the following:

- Evolution of the volatile phase components of smoke with varying puff numbers

a) by sampling with a Grob syringe

b) by sampling on the smoking machine CSM 10

- Effect of TPM on the components of the volatile phase

- Effect of sampling procedure on the components of the volatile phase.

\section{PRINCIPLES AND METHODS}

For practical reasons the following components only were considered:

$\begin{array}{ll}\text { Methanol } & \mathrm{CH}_{3} \mathrm{OH} \\ \text { Acetaldehyde } & \mathrm{CH}_{3} \mathrm{CHO} \\ \text { Acetonitrile } & \mathrm{CH}_{3} \mathrm{CN} \\ \text { Acetone } & \mathrm{CH}_{3} \mathrm{COCH} \\ \text { Isoprene } & \mathrm{CH}_{2}=\mathrm{CH}_{3}-\mathrm{C}\left(\mathrm{CH}_{9}\right)=\mathrm{CH}_{2} \\ \text { Methyl ethyl ketone } & \mathrm{CH}_{3} \mathrm{COCH}_{2} \mathrm{CH}_{3} \\ \text { Benzene } & \mathrm{C}_{6} \mathrm{H}_{6} \\ \text { Toluene } & \mathrm{C}_{6} \mathrm{H}_{5} \mathrm{CH}_{3}\end{array}$

All cigarettes tested were selected on a weight and pressure-drop basis, and afterwards conditioned for a

- Presented at the meeting of the CORESTA Smoke Study Group held in Rome in October 1971. minimum of 48 hours in a container with a cooling system at the normal storage conditions of $21^{\circ} \mathrm{C}$ and $60 \%$ R. H. (relative humidity).

Our tests were conducted according to Coresta parameters.

The study of volatile components in smoke was carried out with a gas-chromatographic apparatus with a gas valve in which a calibrated tube of $I \mathrm{ml}$ is incorporated.

\section{I Chromatographic Analysis}

Apparatus: $\quad F \times M 700$ with double column

Detector: FID

Columns: SS $6^{\prime} \times 1 / 8^{\prime \prime}$, Porapak $Q, 150-200$ mesh Injector $230^{\circ} \pm 10^{\circ} \mathrm{C}$

Temperatures: Detector $290^{\circ} \pm 10^{\circ} \mathrm{C}$ Column $70^{\circ} / 210^{\circ} \mathrm{C}$, programme $5 \% \mathrm{~min}$.

Carrier gas: $\quad \mathrm{N}_{2}$ (purity $99.99 \%$ ), $30 \mathrm{ml} / \mathrm{min}$.

\section{RESULTS}

4.I Identification of the Components and Stability of Their $R f$

The components were identified by comparison with a calibrating solution containing $1 \%$ (vol./vol.) of the pure component dissolved in n-octane.

The stability of their Rf was determined on 10 respective values, $\mathrm{nl}$. on 10 smoked cigarettes (measurement of $\mathrm{Rf}$ values from the injection point).

As Table 1 reveals, the stability of the $\mathrm{Rf}$ values of the different components in the volatile phase of smoke is excellent.

\subsection{Reproducibility of the Gas-Chromatographic Method}

The reproducibility of the method was studied first by complete smoking with the help of a Grob syringe, for 3 types of cigarettes:

- cigarettes with a cellulose acetate filter,

- cigarettes with a triple charcoal filter,

- cigarettes without filter (after removal of the filtering material).

For each test 10 cigarettes were smoked and the standard-deviation (s) and coefficient of variation (v) 
Figure 1. Gas chromatography of an artiflcial mixture.

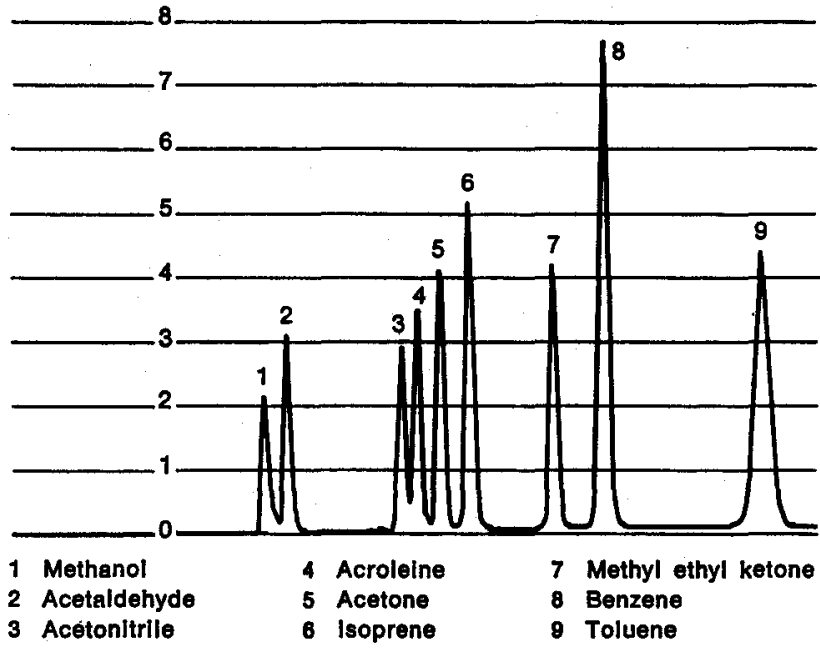

values determined by measuring the peak height instead of the area of the curve.

In another test, and for our own information, we examined the reproducibility of the method of smoking on the CSM 10.

In fact the comparison of the two methods is not valid since by sampling on a smoking machine only the dispersion of one-puff-values can be calculated and
Figure 2. Gas chromatography of the volatile phase of cigarette smoke.

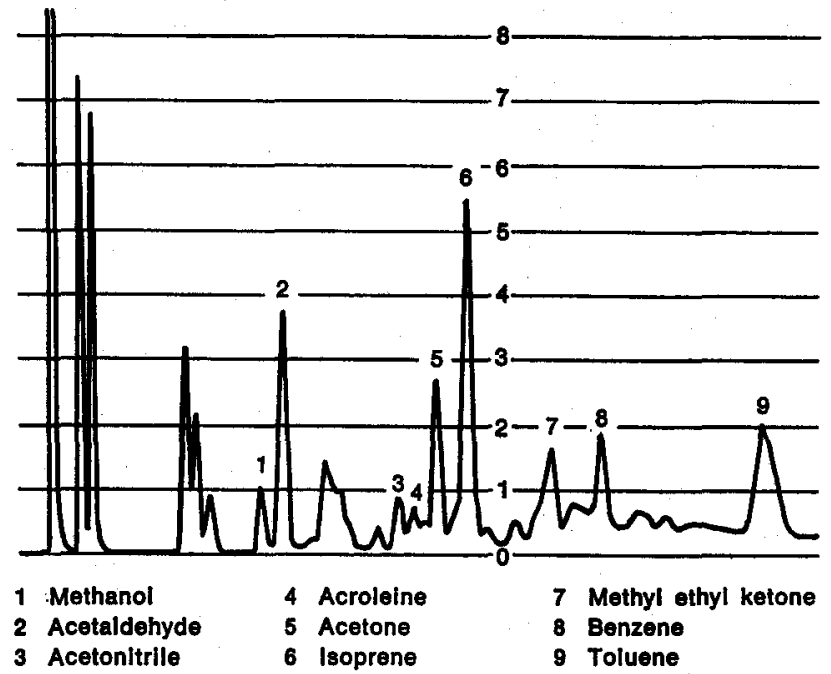

there is no possibility of collecting the whole volatile phase of a given cigarette.

In order to achieve this objective we analysed each 5 th puff of 10 identical cigarettes by aspiration of the smoke through the gas valve, surmounted by a Cambridge filter.

Table 1. Stability of Rt $(\mathrm{mm})$.

\begin{tabular}{|c|c|c|c|c|c|c|c|c|}
\hline & Methanol & $\begin{array}{l}\text { Acetal- } \\
\text { dehyde }\end{array}$ & $\begin{array}{l}\text { Aceto- } \\
\text { nitrile }\end{array}$ & Acetone & Isoprene & $\begin{array}{c}\text { Methyl- } \\
\text { ethyl ketone }\end{array}$ & Benzene & Toluene \\
\hline \multirow{10}{*}{ Rf } & 79 & 90 & 127 & 139 & 153 & 176 & 186 & 238 \\
\hline & 78 & 89 & 126 & 139 & 153 & 176 & 196 & 239 \\
\hline & 77 & 88 & 125 & 137 & 151 & 175 & 195 & 236 \\
\hline & 78 & 89 & 126 & 138 & 153 & 176 & 186 & 238 \\
\hline & 78 & 88 & 125 & 137 & 152 & 175 & 195 & 235 \\
\hline & 76 & 86 & 124 & 136 & 150 & 174 & 194 & 232 \\
\hline & 77 & 88 & 125 & 138 & 152 & 176 & 186 & 235 \\
\hline & 76 & 87 & 124 & 136 & 150 & 174 & 193 & 233 \\
\hline & 76 & 87 & 123 & 136 & 150 & 173 & 193 & 233 \\
\hline & 76 & 87 & 124 & 136 & 150 & 173 & 194 & 232 \\
\hline$\overline{\mathrm{x}}(\mathrm{mm})$ & 77 & 88 & 125 & 137 & 151 & 175 & 195 & 235 \\
\hline$s(\mathrm{~mm})$ & 1.05 & 1.14 & 1.14 & 1.18 & 1.34 & 1.18 & 1.18 & 2.30 \\
\hline$v(\% / 0)$ & 1.36 & 1.30 & 0.91 & 0.86 & 0.89 & 0.67 & 0.61 & 0.99 \\
\hline
\end{tabular}

Table 2. Sampling of the total volatile phase with the syringe.

\begin{tabular}{|c|c|c|c|c|c|c|c|c|c|}
\hline \multirow[b]{2}{*}{ Components } & \multicolumn{3}{|c|}{ With acetate filter } & \multicolumn{3}{|c|}{ With charcoal filter } & \multicolumn{3}{|c|}{ Without filter } \\
\hline & $\begin{array}{c}\overline{\mathbf{x}}_{1} \\
(\mathrm{~mm})\end{array}$ & $\begin{array}{c}\mathbf{s}_{1} \\
(\mathbf{m m})\end{array}$ & $\begin{array}{c}v_{1} \\
(\% \%)\end{array}$ & $\underset{(\mathrm{mm})}{\overline{\mathrm{x}}_{2}}$ & $\begin{array}{c}\mathrm{s}_{2} \\
(\mathrm{~mm})\end{array}$ & $\begin{array}{c}v_{2} \\
(\% \%)\end{array}$ & $\underset{(\mathrm{mm})}{\overline{\mathrm{x}}_{3}}$ & $\begin{array}{c}\mathbf{s}_{\mathbf{3}} \\
(\mathbf{m m})\end{array}$ & $\begin{array}{c}v_{8} \\
(\% \%)\end{array}$ \\
\hline Methanol & 12 & 1.6 & 13.0 & 7 & 1.2 . & 16.5 & 20 & 2.8 & 13.0 \\
\hline Acetaldehyde & 49 & 2.2 & 4.5 & 60 & 5.2 & 8.7 & 73 & 5.7 & 7.7 \\
\hline Acetonitrile & 10 & 1.2 & 12.0 & 11 & 1.6 & 14.7 & 24 & 2.5 & 10.5 \\
\hline Acetone & 52 & 2.8 & 5.4 & 38 & 4.2 & 11.0 & 76 & 4.4 & 5.7 \\
\hline Isoprene & 88 & 3.4 & 4.0 & 76 & 7.2 & 9.5 & 106 & 7.3 & 6.8 \\
\hline Methyl ethyl ketone & 22 & 1.6 & 7.3 & 22 & 2.5 & 11.3 & 40 & 3.3 & 8.2 \\
\hline Benzene & 25 & 4.1 & 16.0 & 26 & 3.9 & 15.1 & 49 & 3.8 & 7.8 \\
\hline Toluene & 39 & 4.0 & 10.0 & 39 & 4.5 & 11.6 & 77 & 6.3 & 8.1 \\
\hline
\end{tabular}


Table 3. Sampling of the volatile phase of the 5th puff on a smoking machine (cigarette without filter).

\begin{tabular}{lr|r|r}
\cline { 2 - 4 } & $\overline{\mathrm{x}}(\mathrm{mm})$ & $\mathrm{s}(\mathrm{mm})$ & $\mathrm{v}(\%)$ \\
\hline Methanol & 10 & 1.5 & 15.4 \\
Acetaldehyde & 67 & 4.6 & 6.9 \\
Acetonitrile & 14 & 1.8 & 12.9 \\
Acetone & 48 & 2.9 & 6.1 \\
lsoprene & 108 & 6.6 & 6.1 \\
Methyl ethyl ketone & 20 & 1.9 & 9.4 \\
Benzene & 17 & 1.4 & 8.1 \\
Toluene & 20 & 3.8 & 19.0 \\
\hline
\end{tabular}

$\overline{\mathrm{s}}=\mathbf{3 . 5 2}$

\subsection{Variations of the Volatile Phase Components with Puff Number}

In order to simplify our task we examined only the 2nd, the 5th and 8th puffs of each cigarette by sampling with the Grob syringe as well as by direct aspiration with the smoking machine.

We proposed thus to follow the variation of the volatile smoke components with the combustion of the cigarette.

4.3.1 Sampling with the Syringe: Before each sampling it is necessary to effect complete smoking of a cigarette by means of the syringe, in order that it undergoes the necessary impregnation followed by two or three rinsings with air.

Without this precaution the first sampling would never correspond to the next ones, and give lower results.

The puffs which do not have to undergo chromatographical analysis are simply aspirated on the smoking machine.

Three types of cigarettes were tested:

- cigarettes with double active charcoal filter,

- cigarettes with triple active charcoal filter,

- cigarettes from which the filtering material was removed.

The results are mentioned in Figures 3 to 5 and are mean values of three determinations.

4.3.2 Sampling with Smoking Machine: We tried to draw a comparison between the variations of the volatile phase sampled with a syringe and with a smoking machine.

We therefore made this comparative test only with plain cigarettes.

Cigarettes for this analysis are placed immediately on the gas valve of the chromatograph and, the machine being set on a $35 \mathrm{ml}$ puff volume, aspiration is taken through the valve.

As soon as the puff is aspirated it is immediately injected into the column of the apparatus.

\subsubsection{Comments:}

- In all tests the contents of volatile phase components increase with the puff number.

The volatile phase varies in the same way as the particulate phase in the course of the combustion of the cigarette.

- Independently of the way of sampling, syringe or smoking machine, we observed a similar variation.

- The amount of volatile phase components of puffs sampled with smoking machine is, except in one or two cases, greater than that obtained by aspiration with the syringe.

This may possibly result from an impregnation of the syringe, excluding any loss of components, the more the time elapsed between sampling and injection increases.

With a smoking machine, however, sampling and injection are two simultaneous operations which reduce the time interval to its minimum (see Fig. 6).

\subsection{Effect of the TPM on the Content of the Different Volatile Phase Components}

It seemed interesting to us to examine whether the TPM of the smoke trapped by the Cambridge filter could, at least partially, collect the volatile phase components.

To make this clearer, we operated in the following way:

A cigarette is smoked with the Grob syringe, the volatile phase which passes through the Cambridge filter is injected into the gas chromatograph.

The obtained values, namely the peak heights, constitute the reference data.

Through the same Cambridge filter we aspirate, with the machine, the smoke of the 2nd, 3rd and $4^{\text {th }}$ cigarettes, and then collect, with the syringe, the volatile phase of the $5^{\text {th }}$ cigarette for analysis.

In the same way we collect the volatile phases of the 8th and 1oth cigarettes, which are injected into the column.

The values mentioned in Table 4 represent the means of 4 identical tests, and thus a total of 40 smoked cigarettes.

Table 4.

\begin{tabular}{l|r|r|r|r}
\hline $\begin{array}{r}\text { No. of tested } \\
\text { cigarette }\end{array}$ & 1st & 5th & 8th & 10th \\
\cline { 2 - 5 } & \multicolumn{4}{|c}{$\bar{x}(\mathrm{~mm})$} \\
\hline Components & \multicolumn{4}{|c|}{} \\
\hline TPM (mg) & 40 & 200 & 310 & 420 \\
\hline Methanol & 24 & 26 & 26 & 25 \\
Acetaldehyde & 79 & 81 & 77 & 67 \\
Acetonitrile & 27 & 28 & 30 & 24 \\
Acetone & 80 & 81 & 83 & 79 \\
Isoprene & 108 & 117 & 123 & 110 \\
Methyl ethyl ketone & 39 & 44 & 43 & 38 \\
Benzene & 45 & 48 & 46 & 39 \\
Toluene & 77 & 81 & 98 & 67 \\
\hline
\end{tabular}

Weight of condensate after smoking of the 10th cigarette: $420 \mathrm{mg}$. 
Figure 3. Varlations of the volatile phase componente with puff number.

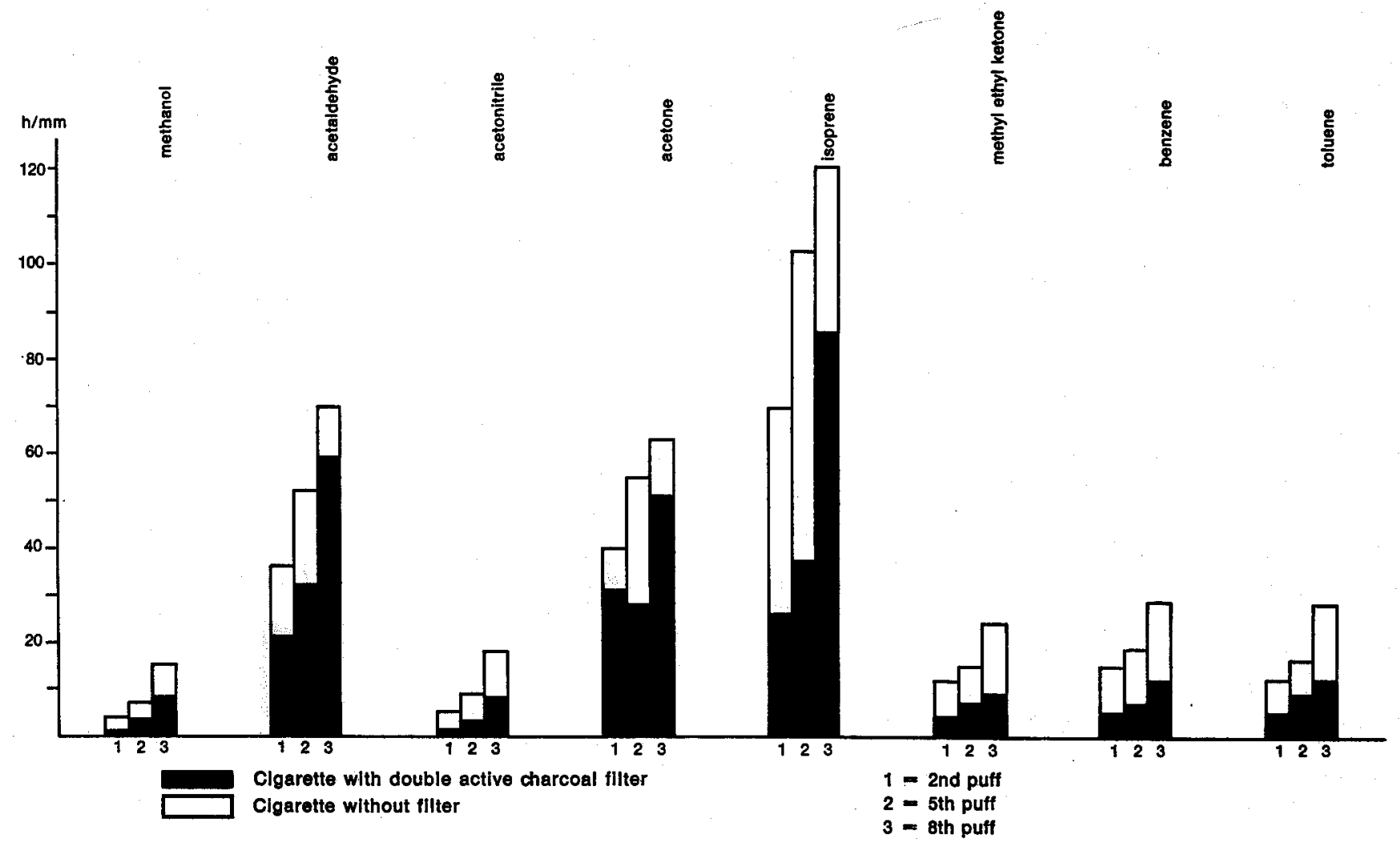

Figure 4.

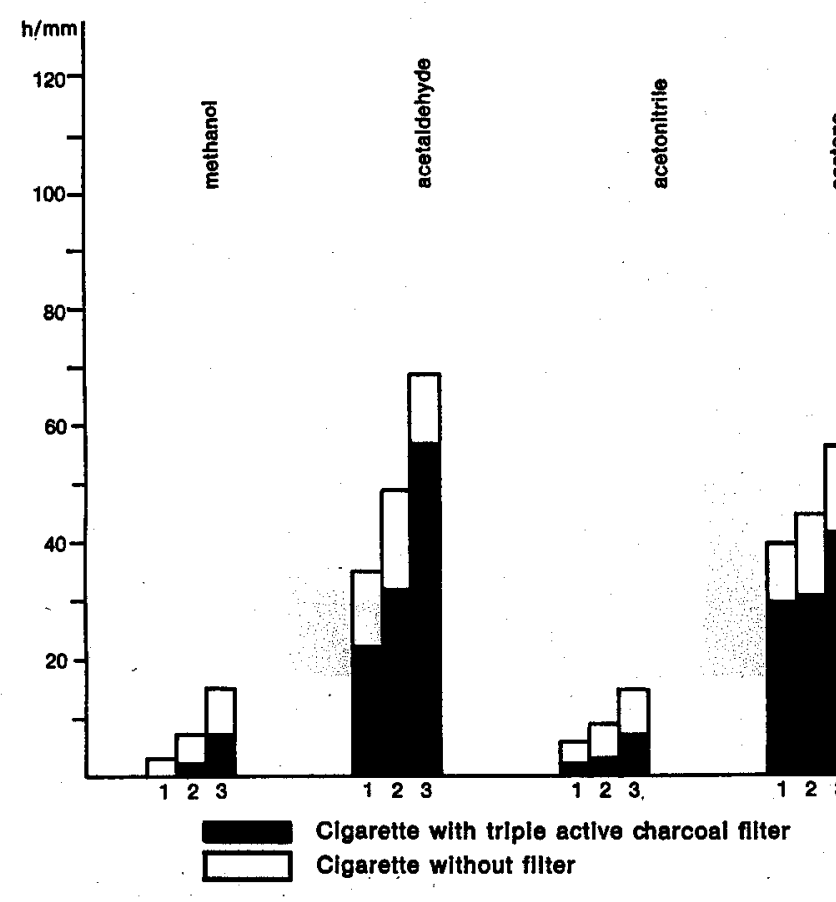

\subsubsection{Comments:}

- Reading these results, we observe that the contents of the volatile phase components of the cigarette smoke depend hardly or not at all, at least after the 1st cigarette, on the quantity of condensate deposited on the Cambridge filter trough which it passes, since the amount of each component remains practically the same, within the limits of experimental errors.

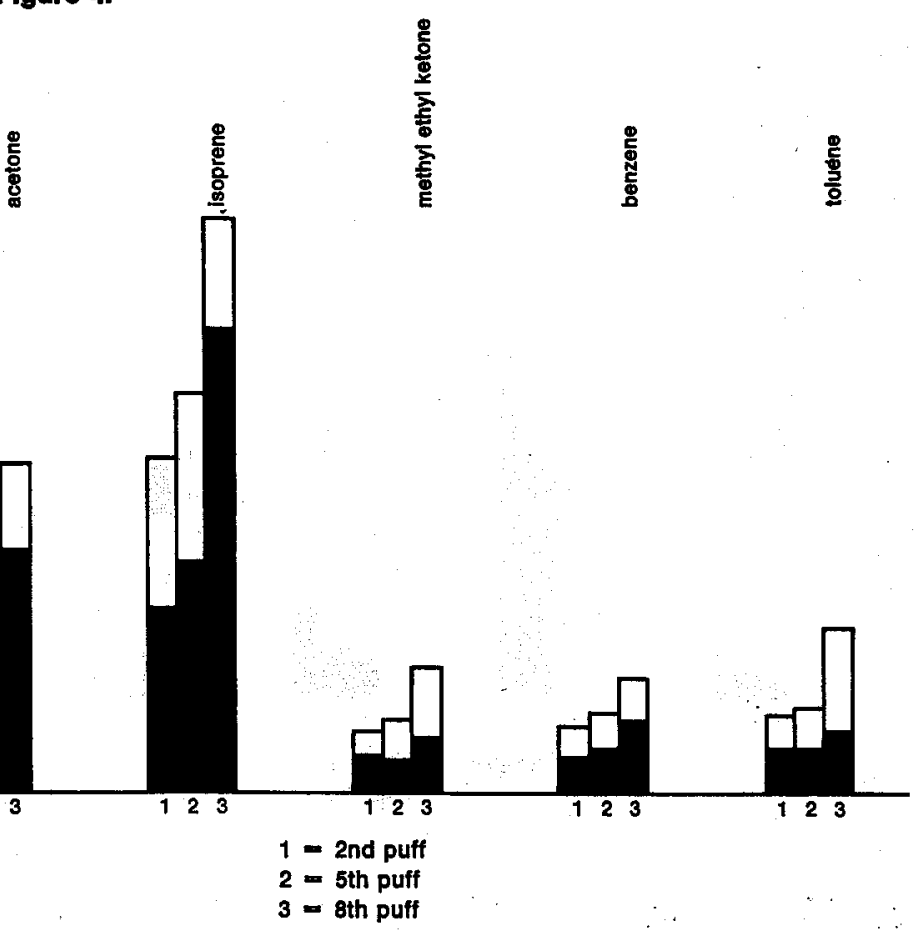

- From examination of the volatile phase of the 1oth cigarette we observe that the values tend to decrease, which may be explained as the beginning of staturation of the Cambridge filter by smoke condensate. When we tried to smoke more than 10 cigarettes the filter was rapidly choked up by the TPM during smoking of the 11th cigarette.

Its condensate weight reached $420 \mathrm{mg}$ after smoking of 10 cigarettes. 
Figure 5. Retention with the puff number.

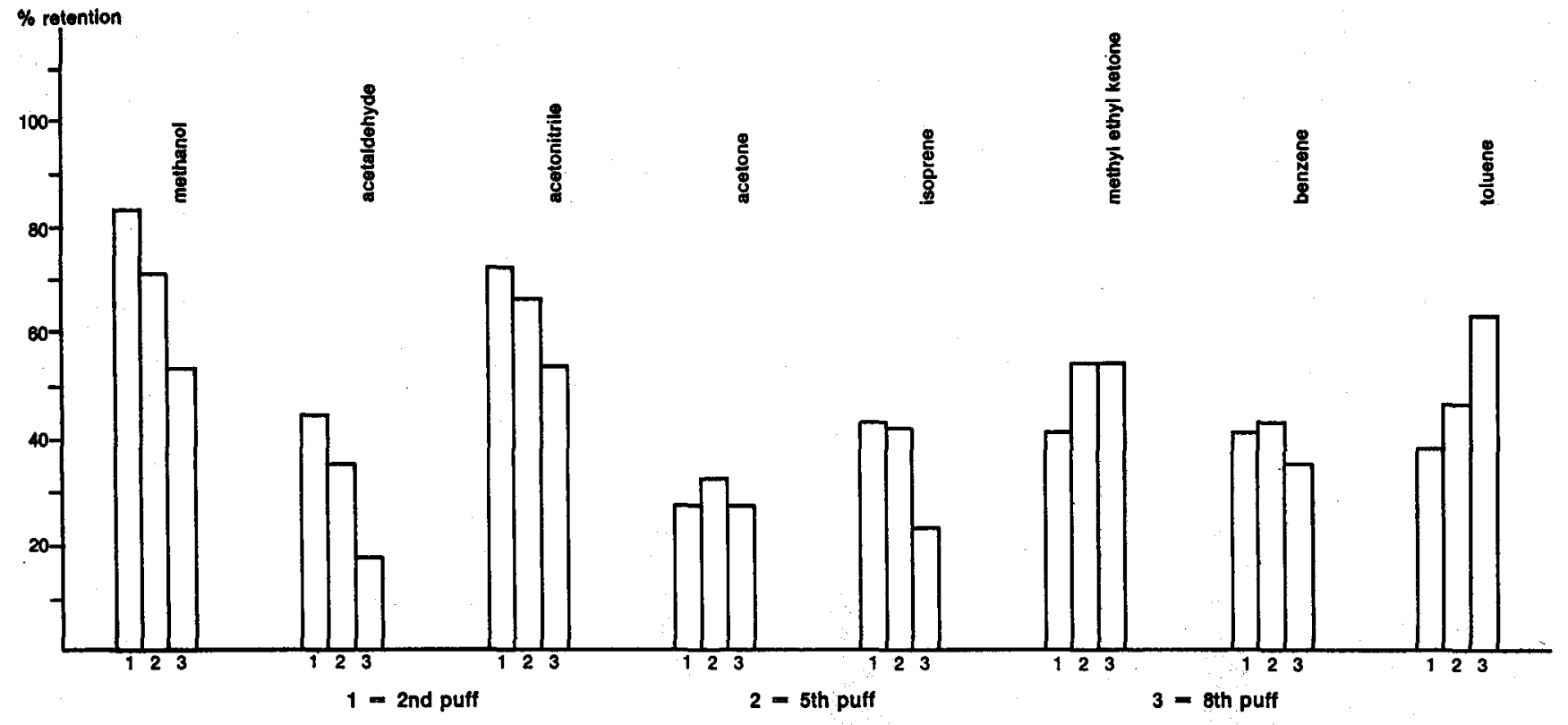

Figure 6.

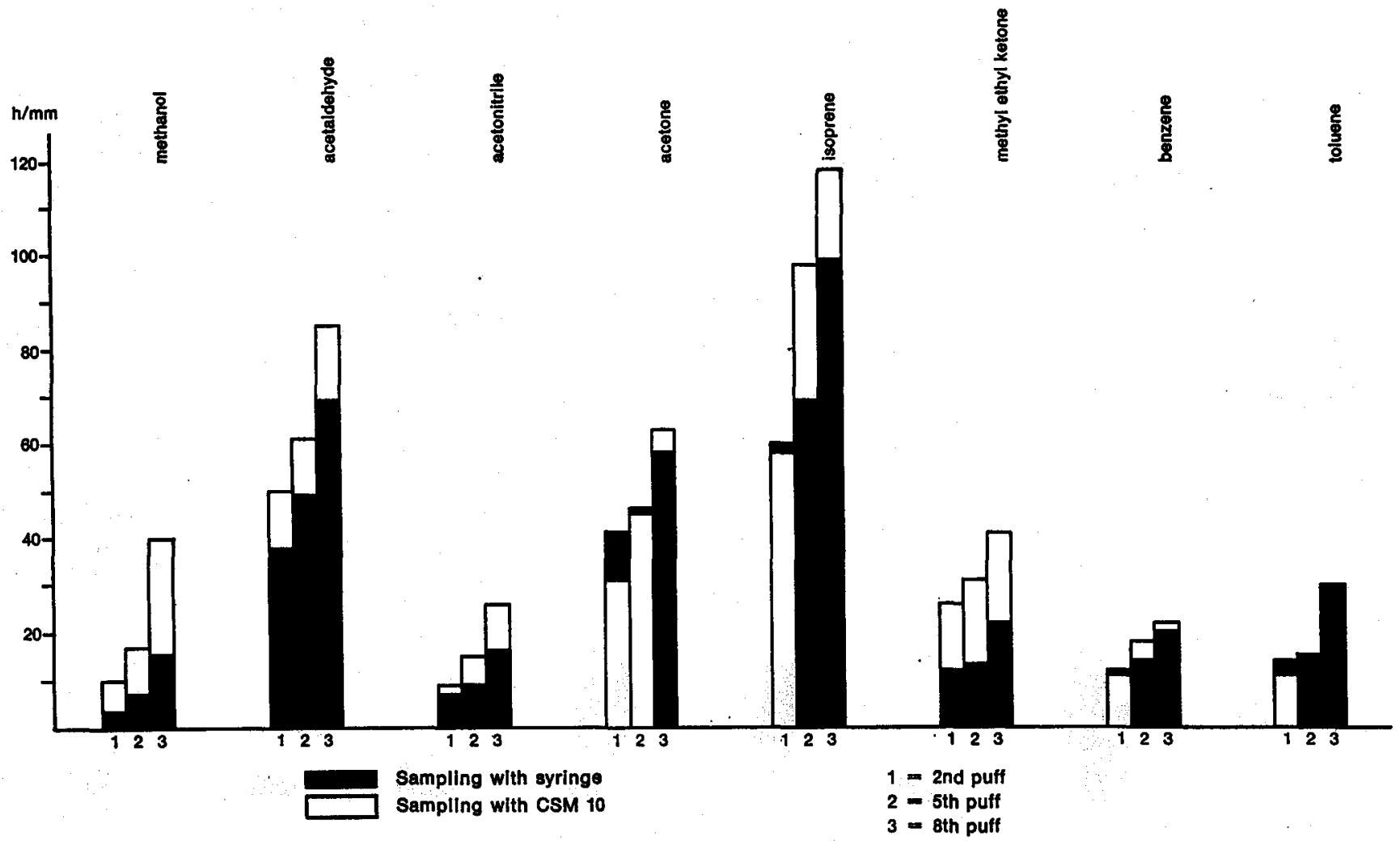

4.5 Effect of Sampling Procedure on the Volatile Phase Components

4.5.1 Total Smoke of the Cigarette: To answer this question we did a comparative analysis of the total volatile phase of the smoke sampled with the Grob syringe, according to the two following methods:

- Direct aspiration through a Cambridge filter and injection;

- Collection of the total phase (smoking without
Cambridge filter), then injection of the syringe contents through a Cambridge filter placed on the gas valve of the chromatograph.

This test, the results of which were completely confirmed by a second test, was the object of a triple determination.

4.5.2 Comments: As shown in Figure 7, the amount of volatile phase components, except for benzene and toluene, increases when the volatile phase is sampled from the total phase collected in the syringe. This 
Figure 7. Smoking of the whole cigarette with and with out Cambridge filter respectively.

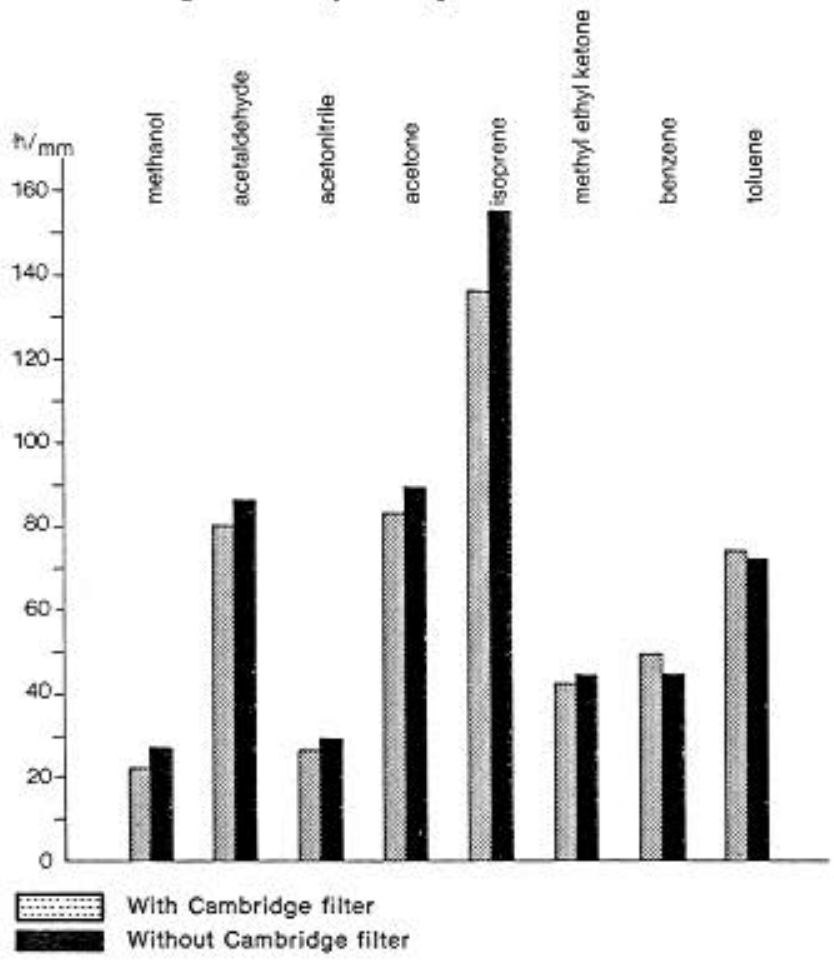

observation may be explained by the fact that the condensate on the inner side of the syringe prevents too great impregnation of the volatile components. As for the small decrease observed in the amounts of benzene and toluene, this could be caused by partial dissolution of these two substances, which are moreover somewhat less volatile, in the smoke condensate, resulting from a more intimate contact between the particulate and volatile phases.

Considering these observations, it seems more judicious to study the volatile phase from the total phase and not from direct sampling through a Cambridge filter.

4.5.3 Puff by Puff: In order to examine this question a comparison of the triplicate results for the 2nd, 5 th and 8th puffs was made by sampling according to the three following methods:
- Collection of the total smoke phase and injection of the volatile phase issuing from this phase (aspiration without Cambridge filter);

- Sampling of the volatile phase through a Cambridge filter impregnated with the smoke condensate of the preceding puffs, then direct injection;

- Collection of the volatile phase, each time through a new Cambridge filter, followed by direct injection.

\subsubsection{Comments (see Table 5 and Fig. 8):}

- By injection of the volatile phase of the considered puff resulting from the total phase collected in the syringe, we observe that the peaks are systematically higher than those obtained after examination of the volatile phase sampled directly through a Cambridge filter.

Although, for the 2nd puff, the difference is not considerable, it does, however, become more important when comparing the results of the 8 th puff.

The explanation of this phenomenon can be found in the fact that the condensation of the particulate phase on the inner side of the syringe prevents, partially, impregnation by the volatile components.

The observed results, puff by puff, confirm exactly those mentioned in the previous test in connection with the complete smoke of the cigarette.

- By sampling each time through a new Cambridgc filter, we obtain results systematically inferior to those obtained after passing the volatile phase through the Cambridge filter impregnated with the condensate of the previous puffs.

From this test we observe that the ratio between the peak heights $\left(\overline{\mathbf{x}}_{2} \mid \overline{\mathrm{x}}_{s}\right)$ of the same component increases between the 2nd and 5 th puffs, and decreases between the $5^{\text {th }}$ and the 8 th puffs. So we can suppose that the relation will tend to I when conducting this test further than the 8th puff, which might confirm that the condensate collected on the Cambridge filter has little or no effect on the amount of the volatile phase components of the smoke (see par. 4.4.1).

Table 5.

\begin{tabular}{|c|c|c|c|c|c|c|c|c|c|}
\hline \multirow[b]{2}{*}{ Components } & \multicolumn{3}{|c|}{$\begin{array}{l}\text { Without Cambridge filter } \\
\qquad \overline{\mathbf{x}}_{1}(\mathrm{~mm})\end{array}$} & \multicolumn{3}{|c|}{$\begin{array}{l}\text { Impregnated Cambridge filter } \\
\qquad \bar{x}_{2}(\mathrm{~mm})\end{array}$} & \multicolumn{3}{|c|}{$\begin{array}{c}\text { New Cambridge filter } \\
\overline{\mathbf{x}}_{3}(\mathrm{~mm})\end{array}$} \\
\hline & 2nd & 5 th & 8th & and & 5 th & 8th & 2nd & 5th & 8th \\
\hline Methanol & 7 & 18 & 30 & 7 & 18 & 31 & 3 & 5 & 15 \\
\hline Acetaldehyde & 46 & 78 & 109 & 49 & 60 & 81 & 35 & 37 & 60 \\
\hline Acetonitrile & 9 & 20 & 29 & 7 & 19 & 27 & 5 & 7 & 14 \\
\hline Acetone & 38 & 67 & 91 & 38 & 60 & 73 & 29 & 37 & 53 \\
\hline Isoprene & 67 & 137 & 168 & 67 & 105 & 122 & 56 & 59 & 94 \\
\hline Methyl ethyl ketone & 19 & 31 & 41 & 20 & 30 & 35 & 14 & 13 & 22 \\
\hline Benzene & 17 & 23 & 32 & 22 & 24 & 25 & 13 & 11 & 18 \\
\hline Toluene & 23 & 31 & 44 & 25 & 49 & 51 & 17 & 13 & 27 \\
\hline
\end{tabular}




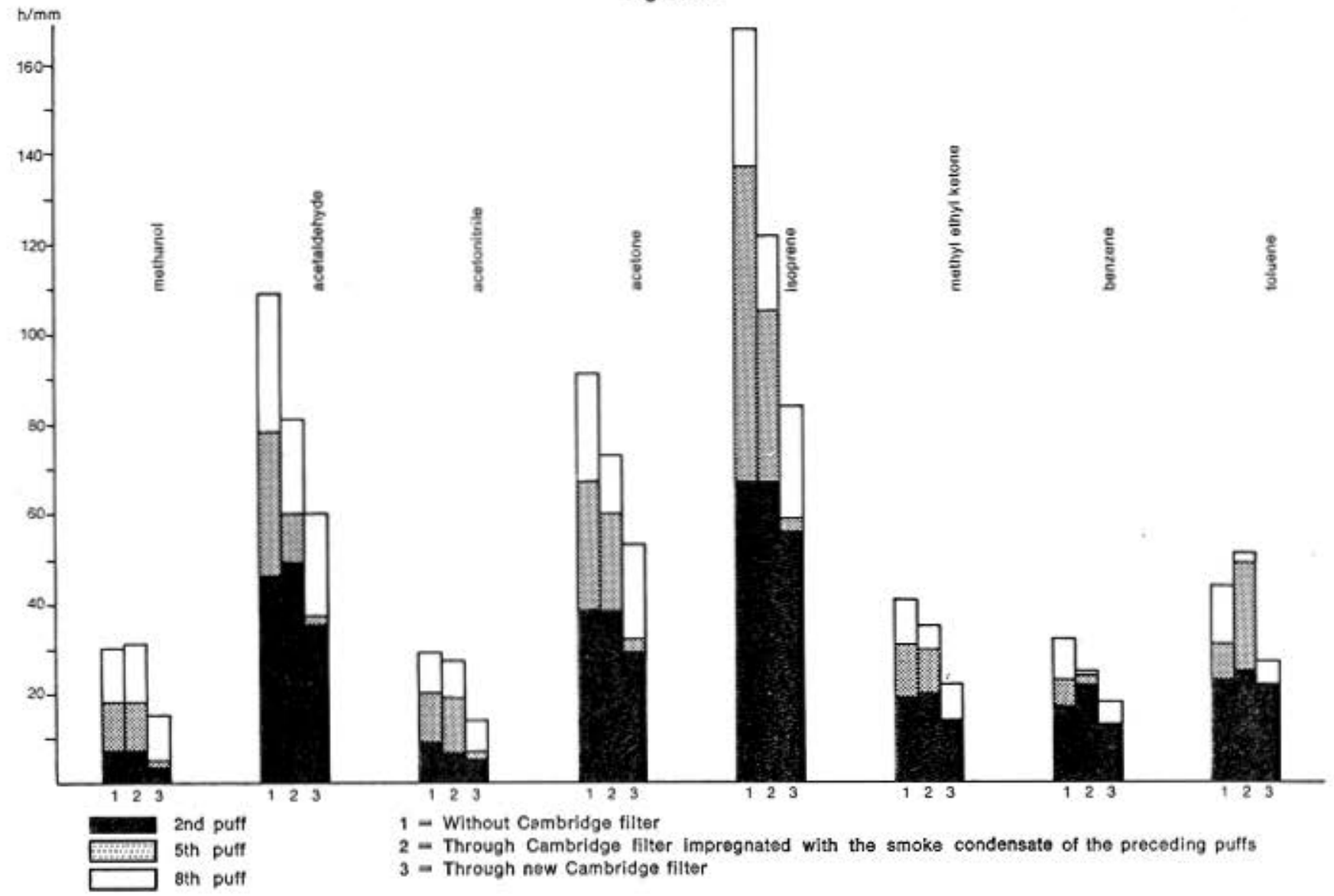

\section{SUMMARY}

- The examined components in the volatile phase of cigarette smoke increase with the puff number, in the same way as does the smoke condensate.

The variation progresses similarly whether sampling with the Grob syringe or the smoking machine.

However, when using the syringe we obtain lower values.

- The amount of particulate matter on a Cambridge filter has little or no effect on the retention of the volatile phase components by this particulate matter, at least after the smoking of the first cigarette.

- The volatile phase, resulting from the total phase collected in the syringe, gives, with the exception of benzene and toluene, higher values than those obtained by direct sampling through a Cambridge filter, both in the complete cigarette smoke test and in the puff-by-puff test.

- By sampling the different puffs each time through a new Cambridge filter we observe that values are systematically lower than those obtained by aspiration of the respective puffs through one and the same Cambridge filter.

\section{ZUSAMMENFASSUNG}

- Die untersuchten Inhaltsstoffe der flüchtigen Phase des Cigarettenrauches nehmen in Abhängigkeit von der Zugzahl in gleicher Weise wie das Rauchkondensat zu.
Die Veränderung vollzieht sich bei Probenahme mit Hilfe der Grobschen Spritze in ähnlicher Weise wie bei der Probenahme durch die Rauchmaschine.

Bei Benutzung der Spritze erhalten wir jedoch entsprechend niedrigere Werte.

- In einem Cambridge-Filter wird die Retention der Bestandteile der flüchtigen Phase zumindest nach dem Verrauchen der ersten Cigarette nicht oder nur wenig durch die Menge der auf dem Filter niedergeschlagenen Partikelphase beeinfluBt.

- Die flüchtige Phase zeigt, wenn sie aus dem in der Spritze aufgefangenen Gesamtkondensat gewonnen wird, bei Ausnahme von Benzol und Toluol höhere Werte als wenn sie direkt durch einen CambridgeFilter aufgefangen wird. Dies gilt sowohl für die Untersuchung des Gesamtrauches einer Cigarette als auch für die Analyse des Rauches der einzelnen Züge.

- Bei Probenahme der einzelnen Züge auf einem jeweils neuen Cambridge-Filter beobachten wir, daß die Werte systematisch niedriger sind als bei Verwendung eines einzigen Filters für die entsprechenden Züge.

\section{RESUME}

- Les composants examinés dans la phase volatile de la fumée de cigarette augmentent en fonction du numéro d'ordre des bouffées, de la même façon que le condensat de fumée.

Cette variation progresse de façon similaire, que le 
prélèvement s'opère à la seringue de Grob ou à la machine à fumer.

Cependant, en utilisant la seringue, on obtient des valeurs respectivement inférieures.

- Sur un filtre Cambridge, la quantité de matière particulaire n'influence peu ou pas la rétention des composants de la phase volatile de la fumée, du moins après la première cigarette fumée.

- La phase volatile, issue de la phase totale collectionnée dans la seringue, donne, exception faite potar le benzène et le toluène, des valeurs supérieures à celles obtenues par son prélèvement direct à travers un filtre Cambridge, et ceci vaut aussi bien dans le test de la fumée complète de la cigarette que dans le test bouffée par bouffée.

- Par prélèvement des différentes bouffées chaque fois à travers un filtre Cambridge propre, nous obtenons des valeurs systématiquement inférieures à celles obtenues par aspiration des bouffées respectives à travers un seul et même filtre Cambridge.

\section{REFERENCES}

I. Kensler, C. J., S. P. Battista : New Engl. J. Med. 269 (1963) 1161.

2. Izard, C., P. Testa: Annales SEITA 6 (1968) 121.

3. Wynder, E. L., D. Hoffmann: „Tobacco and tobacco smoke", Academic Press, New York, London, 1967.

4. Grob, K.: Beitr. Tabakforsch. 3 (1965) 243.

The authors' address:

Tabacofina $5 A$, Seroice de recherche, clo Ed. Laurens, 61 Route de Chêne, CH-1208 Genève (Switzerland). 